\title{
HERITAGE AT RISK IN BRAZIL: WHAT LESSONS CAN WE LEARN FROM THE REGENERATION OF ROYAL ARSENAL, EAST LONDON?
}

\author{
R. S. Citron ${ }^{1 *}$, J. P. Talamini ${ }^{2}$ \\ ${ }^{1}$ Dept. of Architecture and Urbanism, IMED, Passo Fundo Brazil, Rafaela.citron@imed.edu.br \\ ${ }^{2}$ Dept. of Architecture and Urbanism, IMED, Passo Fundo Brazil, Josiane.talamini@imed.edu.br
}

Commission II, WG II/8

KEY WORDS: conservation, planning, adaptive reuse, documentation

\begin{abstract}
:
All over the world, historic building in city centres are being demolished to give way to new (and taller) developments. In most cases, there isn't even any kind of documentation of the historic buildings before its demolition. This is a very usual phenomenon in Brazil, where building conservation is a recent subject and only a few architectural styles are considered heritage. This leaves a great number of buildings under no kind of protection, especially in smaller and non-touristic communities. These buildings are usually located in city centres, where taller (and more profitable) developments are encouraged, which puts heritage in even a higher risk of demolition. When historic city centres are regenerated, it usually results in gentrification, with the old housing being replaced by restaurants and shops for tourists. In the UK, in the other hand, heritage conservation has been discussed for many decades, resulting on a good number of heritage-led regeneration examples to be followed. Investments in the conservation of areas of historical interest have turned them into social, cultural and economic benefits. A big difference between the conservation practice in Brazil and in the UK is that in the last one and specially in London, where the demand for new homes grows every year, heritage buildings are usually converted into residential use. Besides, a much greater number of buildings are considered heritage since it's been agreed that the value of a building or an area should be attributed by the community that created it. During the process of adaptive reuse of the building, a accurate survey os required for the planning application, which helps documenting these buildings for future intervention. This paper analyses the regeneration process of Royal Arsenal, Woolwich, in East London and aims to demonstrate why Britain gets to develop and preserve at the same time while in Brazil we usually can only do one or the other. To get to this result, this paper will point out the main differences between the conservation and planning processes in both countries.
\end{abstract}

\section{INTRODUCTION}

There are two scenarios that are worrying about the preservation of the built heritage in Brazil. The first one represents the situation of most of the cities in the interior of the country, nontouristic cities, that see their historical buildings being demolished and replaced by others that represent 'development'. In Brazil, the tombamento (listing process) is, since the 1930s, the only legally recognized way to guarantee the preservation of a historic building (CASTRIOTA, 2007). Thus, when devoid of this protection, demolition and replacement by a new building ends up being the preferred solution of investors and property owners to profit upon the use of the land (SHIPLEY et al, 2006). However, this does not mean that listing would be the solution to safeguarding the architectural heritage in these cities.

The second scenery is the listed historic centres, protected and transformed into an open-air museum, with their buildings preserved but not necessarily included in the daily life of the cities and the people who created them. This is the case of the historical centre of Salvador, well known among researchers in the area of urban conservation. In addition to the process of gentrification which occurred in the Pelourinho area, through the expulsion of the residents for the conversion of the two-storey houses into tourism services, several buildings are in the state of ruins, unused or underutilized. This scenario questions the effectiveness of listing in the safeguarding of heritage and affirms the importance of maintaining the buildings in uses that bring people closer to the buildings.

It is clear that the discussion of what to do with historical buildings is still very much needed in our country. According to
Castriota (2007), conservation problems in Brazil comes partly because we have not absorbed the broad concept of heritage, widespread in European countries and also because of the hesitation of what type of intervention should be carried out in cultural heritage. Carlos Nelson Ferreira dos Santos had his article vetoed by the National Historical Heritage Magazine when discussing the concept of preservation in Brazil:
"The way it has been practiced, preservation is a statute that can displease everyone: the government is responsible for goods that it cannot or does not want to preserve; the owners are irritated against the prohibitions, in their terms, unjust, of full use of a right; the community because, with great sense, cannot understand the maintenance of some buildings, while watching the inexorable and unintelligent demolition of whole sets of meaningful environments." (SANTOS, 1986, Pag. 61)

Decades after this publication, the reality of preservation in Brazil has changed little. While in several European and American countries the community has been heard in decision making concerning the listed buildings, in Brazil the decisions of what to preserve and how is still in the hands of specialists. This tendency is aligned with the contemporary theory of conservation, which has passed the focus in the object (the listed building) to the subject (the community to which it belongs).

To Muñoz Viñas (2005), the purpose of conservation should be to increase the meaning that the heritage building has to people. In this case, the authenticity of the materials and the ' true state '

\footnotetext{
* Corresponding author
} 
of the building are no more important than the values that people attribute to it. In value-led conservation, decisions should be made based on the analysis of the values that the object has for the different people involved (MUÑOS VIÑAS, 2005).

This change of focus is important in the Brazilian case for at least two reasons. First, by recognizing that are the values attributed by the people what should be taken into account and not only the historical and architectural value of the object, many buildings that previously were not recognized as heritage now become. It is known that the criteria for selecting the buildings to be listed in Brazil were, in the 1930s, the authenticity and exceptionality, valuing the colonial architecture and recognizing it as the representative of the country's identity (BONDUKI, 2010). This taste for colonial perpetuates in the present day, being the architectural style that predominates in the listing book (SIMÃO, 2006). For that reason, cities that arose at the beginning of the $20^{\text {th }}$ century, for example, usually do not have any listed buildings.

The second reason is that the decisions of how to preserve the listed building are taken by all involved, from the owner and users of the buildings to the public power and not anymore only by specialists. This means that classical theories of conservation and restoration, such as the notions of authenticity, reversibility, objectivity and minimal intervention advocated by Cesare Brandi, are replaced by the notions of value, use, and meaning (MUÑOS VIÑAS, 2005), which will possibly make the process of approving projects in listed buildings more flexible. So, while currently trying to limit change, the conservation based on contemporary theories will refer to the inevitability of change (CASTRIOTA, 2005), seeking to increase the values assigned to the building.

\section{THE PROBLEM OF ADAPTIVE REUSE IN BRAZIL}

For Brand (1994), it is precisely the fact that the buildings adapt to their users that makes a building survive, while others are demolished. For the author, the buildings that people like are the ones that work well, that can adapt to the people who use them and who show their histories and age. A building to succeed must be periodically renewed (BRAND, 1994, pg. 209). Similarly, for listed buildings to continue to be used and included in urban life, they need to be adapted and modified.

As already mentioned before, the new use of listed buildings should bring people close to it. However, what has been perceived over time is that the vast majority of the historical buildings that are preserved, especially in Brazil, are re-used as museum and other cultural purposes, making it difficult, in some cases, to reintegrate these buildings into daily of the cities. Besides, this use generates a load of historical material that often does not have significant value, but that are exposed in the museums of small cities only to occupy the space destined to the local memory.

To Choay (2006), cultural use is a more difficult way to bring value to a building, and it is a very unprofitable use. For the author, the housing use and the support services, such as small shops, schools, etc, are the ideals for the urban heritage, that is, for the buildings inserted in urban environment and the daily life of its inhabitants. But what happens in Brazil is that in projects for rehabilitation of urban centres, housing is never the focus because there is a view that historical centres should be focused primarily on tourism cultural activities (BONDUKU, 2010).

\begin{abstract}
"Replacing the housing use of the historical areas, as well as the residents living there, means creating cores with no daily life, no shops and services of local character, which tends to generate spaces that remain deserted for a good part of the day. Without residents, the fundamental relations between the physical space and the socio-cultural process of life are destroyed". (BONDUKI, 2010 pg. 316).
\end{abstract}

In addition to this tradition of reusing buildings in historical centres for cultural and tourism purposes, the adaptation of historical buildings into residential use requires transformations that are often not accepted by the preservation bodies for going against classical restoration theories, as previously mentioned. These modifications, however, are necessary because of the new ways of living of nowadays population, which will be different in future generations and so on.

These restrictions imposed by the preservation bodies results in the listing process in Brazil having a negative function, causing neither the owners nor the population to want the buildings to be listed, for fear that the property will end up being unused. However, the listing legislation does not prevent the listed buildings from being modified, it only says that any intervention needs to be authorized by the preservation bodies.

Art. 17. The things that have been listed shall in no case be destroyed, demolished or mutilated, nor, without prior special authorisation of the service of historical and artistic national heritage, be repaired, painted or restored, under penalty of $50 \%$ of the damage caused.

Therefore, the difficulties for the adaptive reuse of listed buildings for housing or other uses different from the cultural ones does not come directly from the listing itself, but rather the interpretation of the technicians who evaluate and take the decisions. Balancing the desire to preserve a building for architectural and historical reasons with the need for change and the expectation of the homeowners to profit upon the property is a challenge that the preservation of the built-up heritage faces (SHIPLEY et al, 2006).

\section{CONSERVATION IN ENGLAND}

In England, the issue of heritage preservation has been discussed since the $16^{\text {th }}$ century, but it was only from the $18^{\text {th }}$ century on that awareness of the value of historical heritage began to grow in England, under the influence of the ideas of John Ruskin and William Morris. With the evolution of heritage concepts, as previously mentioned, the English Heritage, the English organization that manages the national heritage, created in 2008 its definition of conservation, as follows:

"The process of managing changes of significant places in the way that best sustains its asset values, while recognizing opportunities to reveal or strengthen these values for future generations." (MCCAIG, 2013, pq. 4)

According to the book produced by English Heritage (2013), the history of preservation in England can be divided into three moments: monuments, buildings and conservation areas. Influenced by John Ruskin (1819 - 1900), which believed in the minimal intervention to the monument, the preservation of historic buildings in England contemplated, in a first moment, medieval and mainly ecclesiastical buildings, following a policy 
of "repairing as found". In this way, no addition was made in the monument, which remained even with its original use. At the beginning of the $20^{\text {th }}$ century, facing the large number of medieval buildings in use, the second phase of the preservation of the heritage in England begins. Driven by expansions and renovations of urban areas, legislation has become necessary to protect buildings worth of preservation.

The Town and Country Planning Act of 1932 was the first legislation that began to consider buildings of architectural and historical interest in urban planning of cities, still according to English Heritage (2013). Its update, in 1944, introduced the production of a list of buildings to be preserved, where the criterion was, among others, to be 30 years old. This list gave rise to the Listed Buildings, the English listing process.

At first, listing was not very effective in safeguarding historical buildings. Based on the Venice Charter of 1964, only a few changes were allowed to receive new uses, and neither layout nor decorative elements could be altered. This ideal of minimal intervention, although it works in cases of monuments of exceptional interest, such as ecclesiastical monuments, became difficult to be applied to simpler buildings, which were increasingly being part of the list of buildings to be protected. From then on, maintaining the building in use has become a priority for the safeguarding of historical buildings.

In view of this, Planning Policy Guidance Note (PPG) 15: Planning and The Historic Environment (1994-2010), indicated the general principles for changes in listed buildings, which could be requested through a document proving the building's understanding and coherent justification for the proposed modifications. In this note, the preference for modifications that resembled the historical building was removed and from then on the expansions began to use contemporary materials and typologies. The role of these planning documents, from the end of the $20^{\text {th }}$ century, was to balance public interests in the conservation of historical buildings with the private interest in making changes of greater impact on buildings, including their demolition.

The third moment in the history of preservation in England is in the identification and protection of areas of historical interest. The Civic Amenities Act Of 1967 gave the local authorities the right to appoint Conservation Areas. In these areas, even non listed buildings are protected against demolition. Conservation areas arose under the view that preserving individual buildings was no longer sufficient and that preservation should be related to the environment in which it was built (MCCAIG, 2013). In addition, with conservation areas, preservation has passed to the local scale, which facilitated the process, leading the protection process away from the judgment of the elite and the specialists. In this case, local memory becomes the conditioning for preservation.

Currently, grows in England the so-called Heritage-Led Regeneration, which are urban revitalization projects focused on heritage conservation. Investments in the conservation of areas of historical interest have become social, cultural and economic benefits. Historical heritage has contributed to the reinvention of spaces, creating an identity for local communities. In summary, throughout this process they have reached the consensus that the value of each building or area must be attributed by the community that created it. This makes it not feasible to create criteria, neither for their recognition nor for restrictions on changes, as this varies according to each culture. The idea of minimal intervention, which was practiced until the middle of the $20^{\text {th }}$ century, does not result in an adequate response to the wide variety of issues related to the preservation of historical heritage. The conservation of a building or area must therefore be done by recognizing its values and interventions should strengthen them.

In March 2012, the National Planning Policy Framework has been published, which replaced the previous documents. Today, it is this legislation that governs the protection of historical heritage. In conservation areas, any modification that involves the exterior appearance of the building must pass through the planning sector, which it judged based on this document. Decisions are almost always taken by local authorities in a process called Planning Permission. Modifications and extensions are not prohibited as long as they do not result in the loss of the historical values of the buildings.

\section{THE ROYAL ARSENAL NEIGHBOURHOOD}

\subsection{Overview}

The expectation is that until 2026 the population of London will reach again 8 million inhabitants (the population was reduced to 4 million with the creation of the Grater London Plan in 1946). Because of this, the city is going through a great urban planning to receive in a sustainable way the new population, without being necessary to advance over the green belt, which since the postwar conditions the growth of the city.

As previously mentioned, since 1967 England uses the status of Conservation Areas and today there are over 8000 conservation areas in the country, according to information on the British Government website (2017). They are considered areas of historical and architectural interest, where all the built and natural urban set is protected by law. Royal Arsenal, east of London, is considered to be a conservation area. Even so, it is one of the areas designed to develop in the coming years to receive a large number of new dwellings.

In 2001, the Berkeley Homes Company was chosen to, along with The London Development Agency (LDA), the Royal Borough Of Greenwich and the Greater London Authority (GLA), to regenerate Royal Arsenal and transform it, from an old neighbourhood of munitions production into a mixed-use residential neighbourhood, with affordable and market-priced apartments in the same buildings, in addition to shops and services.

Royal Arsenal is on the River Thames in the district of Woolwich, to the east of the docks. It had its peak development during the First World War, when it manufactured most of the war's ammunition. After the second war, it began to fall into the process of decay until its definitive closure in 1967. After that, the British Ministry of Defence began to occupy some of the buildings up to 1994, when the buildings went into disuse (MASTERS, 2010). While many of the factories have been demolished after closure in 1967, many buildings still remain, 22 of them being listed.

According to Berkeley Homes (2016), the Royal Arsenal Development Program foresees the construction of 5000 new dwellings distributed among old warehouses converted into residential and new buildings. In addition, the project includes bars, cafes, libraries and shops, as well as a station of the new train line, the Crossrail, which will enter into operation until 2020. The plan includes restoration and reuse of the old 
warehouses, in addition to expansions and improvements so that buildings can receive new use.

The justification for the changes in the buildings and constructions of new building in the neighbourhood, according to the document presented to the local authority, is held in the argument of the urban vitality that these new developments will bring to the neighbourhood, without losing their original features. In addition, the buildings will be used again, contributing to their preservation.

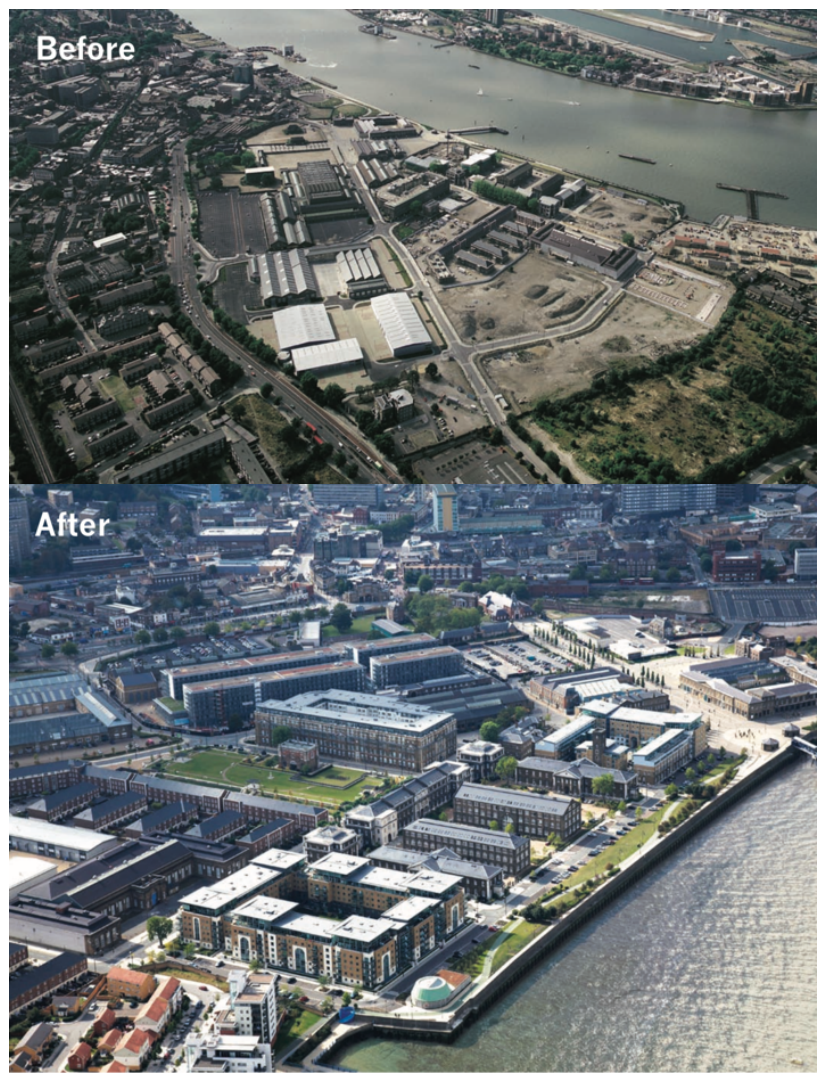

Figure 1: Royal Arsenal, before and after the regeneration $(\mathrm{C}$ BHL

\subsection{The regeneration scheme}

In 2006, a project led by English Heritage called SHARP (The Sustainable Historic Arsenal Regeneration Partnership) have published a document about the regeneration of Royal Arsenal, aiming to share the knowledge to other countries in the world working with similar sites. The information in this chapter has been all taken from this document from 2006, since there aren't many publications about the Royal Arsenal case.

The strategy for the regeneration of Royal Arsenal started in 1993, through the idea of a diversified economy. According to Stevenson (2006), the vision of the masterplan was based on two pillars: the economic potential and the historical value of the site. Besides, it was necessary to create a connection between Woolwich and the Thames river, creating in the middle a neighbourhood where people could live, work and have fun.

Being an industrial zone, the Royal Arsenal neighbourhood was, at the end of the 19th century, a vast complex of factories and their buildings were "large, robust and not necessarily beautiful" (STEVENSON, 2006, pg. 33). According to Stevenson (2006), by 1950 there was about 60 buildings dating between 1690 and 1970, among which 21 are listed, 4 of them being Grade I or II* while the rest of them were Grade II. The masterplan had as its main objectives to give a destination to the listed buildings and making future private investments possible.

With the idea of creating a mixed use neighbourhood in mind, the 31 ha of the site were divided between residential area (in the area closest to the river, giving back to Wellington Road), offices near the main street, in the eastern part of the neighbourhood, museums and other cultural uses near the pier and commercial uses and leisure activities in the southwest part of the neighbourhood, near to the Woolwich Arsenal town centre. This zoning was flexible and eventually changed over time (STEVENSON, 2006).

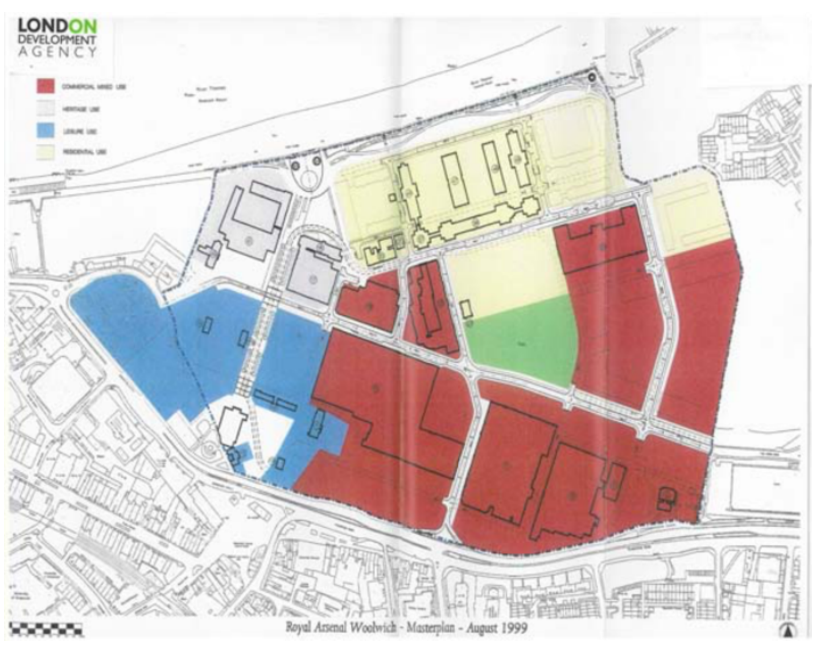

Figure 2: The masterplan from 1999 CLDA

As previously mentioned, the strategy of the masterplan was to keep the greatest number of historic buildings, reusing them for new purposes. It was acknowledged that, due to the typology of military buildings, the reuse of some of the buildings would not be economically viable. Buildings with no historical value were then demolished to give way to new developments. The goal was to create a sense of belonging to the local community and people who would work in the neighbourhood in the future. For this reason, some buildings were pointed out in the masterplan for civic uses.

One of the big keys to the masterplan was the flexibility with which it was thought. The planning strategy was an Outline Applicating, which within the English legislations allows for flexibility. The masterplan was sent as a support for this Outline Application, so it did not contain detailed information about the project. Instead, it presented sufficient information about the destination of the historic buildings, allowing London Development Agency to have time to assess the economic viability of the development and to engage the partners of the private sector, who would later present their own masterplan to the site. The regeneration of a mixed-use site is a complex process, especially when it involves buildings of historical interest. In the case of Royal Arsenal, the masterplan could not have given an accurate use for every building at a first moment and the flexibility strategy was identified as a wise decision over the years (STEVENSON, 2006). The Greenwich Council and the English Heritage had to develop confidence in one another in relation to the commitment in preserving the historic buildings, even when there were changes in the plans over time. 
At the same time that the regeneration proposal should maintain the local character, it also had the challenge of changing the perspective that people had with respect to Royal Arsenal. Because it was a military neighbourhood, people only went there to work, besides the fact that the neighbourhood was hidden behind walls, a common situation in industrial historical sites. The masterplan of Royal Arsenal also predicted routes for access to the Thames, which contributed to the marketing of the neighbourhood as a special and interesting place.

For buildings listed as Grade I, II * and II, the reuse process was relatively easy compared to other historic buildings in the site. Some buildings with less historical importance were demolished to give way to new developments and other were left to be discussed later in the process, as the case of building number 22 , which was initially indicated to be demolished and later have been maintained and largely rebuilt in its interior to support the new apartments. In some cases it was difficult to find new uses for buildings with shed style. An example is building Number 10, which was all rebuilt behind the original façade (STEVENSON, 2006).

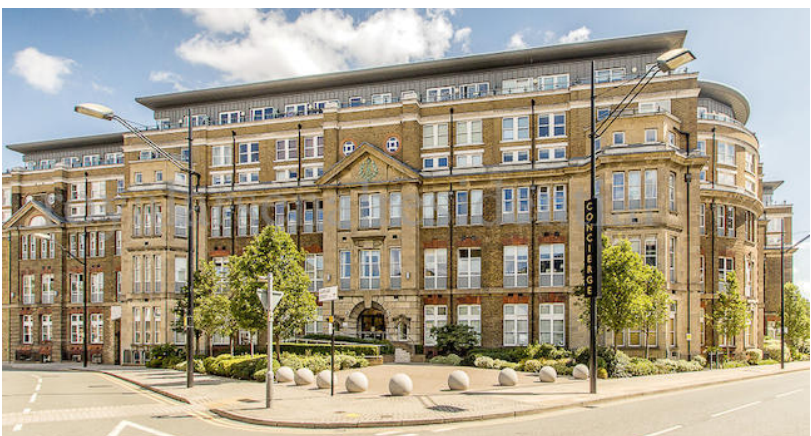

Figure 3: Building 22 after regeneration

In the regeneration process of any historical site, there must be a balance between conserving historical materials and allowing changes to accommodate new uses. It is generally indicated that minimum changes are made, preserving the maximum possible characteristics and materials. One of the most important things that create the characteristics of a building is the external structure. The façade and the volume of the roof is what most people will see, and their understanding and contemplation of the place is going to be based on that. Most of the historic buildings of Royal Arsenal have succeeded in preserving the facades, with minimal changes to accommodate the new uses. Because of the symmetry and repetition of the openings on the facades, the neighbourhood buildings were easy for conversion into apartments. An interesting fact is that the restoration process of the buildings did not include the cleaning of the facades. The neighbourhood was for much of its history a dirty neighbourhood, with many chimneys. The dark tones of the buildings were kept as a reminder of these times.

The buildings typology of the site, however, are not normally easy to adapt into new uses. Finding new uses is important and it is necessary to recognise that difficult decisions will have to be taken. Whenever possible, the internal space of the building must be maintained, but it can often only be saved what realistically can be maintained, rather than what we want to be maintained. For the most part, the neighbourhood buildings were large industrial spaces, and this is an important feature of the buildings, but finding uses compatible with this internal typology was not easy. In large multipurpose projects, such as the RA case, it is inevitable that many of them end up being partitioned inside. The buildings intended for cultural use such as the Firepower and the Greenwich Heritage Centre managed to keep the open space internally and can be appreciated in its original form. However, the buildings converted into housing, like the Grand Store, was inevitably compartmented.

In places with thriving local economy, heritage conservation and economic development can work very well together. This was not the case of Royal Arsenal and decisions of how and what to preserve end up being more difficult. These pressures are impossible to ignore and had to be included in the planning. The fact that the neighbourhood has been transferred to a single agency, the London Development Agency, facilitated property acquisition issues, which can be a complicator in most cases.

In the case of Royal Arsenal and in most projects of this scale with this complexity, especially when it involves historical areas, partnerships between the public and private sector are essential. "The Government must recognize that the top-down planning times have ended and that flexibility and openness to new ideas is essential" (STEVENSON, 2006, pg. 49). The public sector must match public interests but at the same time ensure that the development is viable and sustainable over time. In the case of Royal Arsenal, the public-private partnership was essential to the success of the project. The government was responsible for creating the changing conditions for the private sector to be interested in investing on the site.

The Royal Arsenal complex was a large site with high costs for its repair: decontamination, archaeology, demolitions, structure restorations, etc. In addition, the Southeast region of London was one with the lowest values of London real estate market. There was very little interest on the part of investors in the area and the site had little interest and historical values in the eyes of the community to support the opening of museums and cultural centres on site. Because of that, the public sector (London Development Agency) invested about $£ 45$ million over 9 years to encourage the development of the site. Gradually the market responded to new conditions created. Up to 2006, private sector investment was $£ 147$ million and will reach the amount of $£ 577$ million with the addition of the western part of the neighbourhood (The Warren) (STEVENSON, 2006).

Without bringing the private sector to the process, the developments need to rely on government funding and often become unsustainable. In the case of Royal Arsenal, as soon as there began to be private interest on site, the London Development Agency made a competition to find the partner, where the main requirement was to demonstrate knowledge and sensitivity to intervene in a historic site like Royal Arsenal, as well as experience in planning, high quality projects and goodwill to engage in a masterplan in the long run. The Berkeley Homes Ltd won the competition for the residential part of the project. According to Stevenson (2206), the essential key is to find private sector partners who agree to work in the long run, with large initial investments and with returns that will come slowly.

One of the biggest challenges in the hands of the public initiative is to balance the control of the enterprise in terms of legislation and the promotion of change. While the change benefits residents in various spheres and should be encouraged, it needs to follow and meet the standards like any other construction. In other words, the role of the municipality is twofold: to control the process of change and at the same time encourage it. The same relationship happens in relation to the modifications made in the historical buildings: care must be taken to make sure the 
buildings will be preserved and at the same time allow sufficient changes to make the adaptive reuse viable.

The listing process and protecting historic buildings in the UK is managed by English Heritage and they guide the level of changes allowed in the buildings. English listing not only guarantees the preservation of a building and its non-demolition, but it has the function of ensuring that the modifications that will eventually occur in the building do not compromise its special characteristics. In addition to the listing process and as previously mentioned, the municipality can also declare the area as a conservation area, which is the case of Royal Arsenal. In this case, the historical value of the area as a whole is recognized and the goal is to prevent any new development from damaging the special character of the site. In addition, being within a conservation area, unlisted buildings are also protected. Thus, the demolition of any buildings is subject to approval of the municipality (in this case, the Greenwich Council).

According to Stevenson (2006), one of the greatest lessons learned from the regeneration of the Royal Arsenal neighbourhood is that everyone involved with the project of a historic neighbourhood should be aware of all the values of the historical site, not just the financial values. It is of utmost importance to know what the interests of all the agents involved are, knowing what they think about heritage and what interest they have in it. If the specialists in the field of heritage preservation want to impose their notion of heritage to other parties, it will hardly succeed.

From 1999 onwards, attitudes with relation to heritage preservation in the UK have changed and today it is no longer necessary to suspect the parties involved as it was at the beginning of the regeneration process. Both London Development Agency and Berkeley Homes have an open relationship of trust, understand that heritage and development can walk together, and both can bring benefits to one another. According to Stevenson (2006), there was a convergence between those who believe that preservation is important and those who were investing, but this came only after that essential characteristics of industrial architecture had been demolished in the initial phase of the project, such as the paving of the streets and the railways. Nowadays, all planning approvals released by the Greenwich Council are given on the condition that a survey of the building in question is made.

\section{CONCLUSIONS}

\subsection{Adaptive Reuse}

Considering both cases, especially with regards to the management and intervention in historic buildings, it is clear that there is a urgent need to review the listing process and the allowed adaptations to listed buildings in Brazil. Many buildings of recognized value have been lost due to the difficulty imposed by the preservation bodies in relation to the interventions allowed. Such inflexibility hinders the adaptation of buildings to uses beyond the cultural, since uses such as residential requires more then only minor interventions, as seen in the Royal Arsenal case. Under the justification of preserving its most important characteristics, historic buildings are left unused and risking of being forgotten and lost for the lack of maintenance and recognition of its value by the population.

In Brazil, it is still very common to only reuse historical buildings for cultural uses (museums, culture centre, etc.), especially those a high degree of listing. What has been observed, as already reported, is that the historical centres are increasingly empty of vitality and occupied, most of the time, only by tourists, at very specific times of the day, and promote the "museification" of the buildings and the city centre. The restriction of new uses, besides generating lack of vitality still entails the loss of the notion of belonging by the local population, which, due to the tourist focus of many historical centres, is usually away from its own city centre.

It is clear that any intervention in historical building, whether protected or not, must undergo a feasibility study. What is suggested to change the reality of preservation in Brazil is that other uses get to be considered during the development process, allowing that the historic site will have urban vitality, will be economically sustainable and will offer solutions to social and urban issues, associating development and memory preservation, as observed in the case of the Royal Arsenal.

\subsection{Listing process}

Although much has been debated in heritage events in the country regarding the need for adequacy of the mentioned postures by preservation bodies, there is still much to be done, both regarding listed buildings, whose maintenance, in most cases, is not adequate, being a recent example the museum National in Rio de Janeiro; and in cases where buildings are not listed, but whose value is recognised by the local community.

In addition, it is possible to observe that in the Brazilian reality the listing process of a buildings has not ensured their proper preservation and maintenance, both because what belongs to the government does not receive the necessary financial support for its maintenance, as by the fact that the owners do not recognise, in most cases, the value of the building. This last fact is due to the difficulty in the adequacy and reuse of the listed building due to legal issues of preservation and restoration, generating little financial return, which discourages the owner to invest in the recovery of the property.

There is a need to revise the processes and legislations of protection and listing in Brazil, including in the records of the documented listed building a greater number of information regarding the special characters of the each building, as well as establishing and guiding the actions that are allowed in each property or city centre. However, this is a policy of preservation that would require a change in posture of the preservation bodies that still assume the criterion of minimal intervention, even if it interferes negatively in the feasibility of building use.

\subsection{Planning}

Another point that should be highlighted as fundamental for the valuation of the heritage are the aspects linked to the planning as a whole, allowing the building or the historical set to be again thought as a living urban space. In this sense the case of the Royal Arsenal is exemplary for allowing there to be urban vitality, bringing the community closer to the historical buildings, reusing the structures with compatible uses and proposing the diversity of uses at different times of the day and week.

Still on the planning process, what can be noticed in the Londoner case, and whose application is rare in Brazil, is the analysis of the economic viability of the proposed reuse and the advantages that this new use can bring to the urban space in the short, medium 
and long term. The feasibility study in this case will allow the decision to be the most assertive possible, especially for taking into account that transforming everything into a museum or cultural area makes it difficult to promote attractiveness and has very low financial returns when compared to other uses, such as commercial and residential, for example. Still with regard to economic viability, the planning process of the Royal Arsenal, took into account the future needs and social aspects (affordable housing) that would be part of the urban growth problems foreseen, making the process of appropriation of heritage by the community easier.

Possibly one of the causes of conflicts in the preservation of heritage in Brazil is precisely the difficulty of communicating and compatibilization of the actions of the different organs responsible for interventions in the urban space. It is common to have no agreement between the need for preservation and the need for development. These problems have been corrected gradually by the competent organs in integrated planning processes, however, there are still difficulties in alignments.

The trust that exists between the public sector and the private one in Royal Arsenal is something very rare in Brazil. Planning process and preservation don't usually walk along and most people, especially those involved with real state, do not understand the importance of preserving the past. This is probably the main problem there is in Brazil regarding building preservation. The public sector needs to promote development but at the same time ensure that heritage is being preserved.

\subsection{Documentation}

The stage of intervention in the built heritage is one of the last stages of the preservation process. However, until the actual moment of modification of the building, there are fundamental preliminary processes for gathering data and information indispensable for the adequate development of future interventions. In this way, one of the first steps for the protection and conservation of historical heritage is to know the building that is about to intervene. This stage includes the realization of inventories and detailed architectural survey, from which will be generated reliable information of the current state of conservation of the building, its architectural features and construction systems, as well as historical and documentary data.

In the Royal Arsenal case, the planning application requires a full set of drawings including all original plans and elevations of the building, so that the proposals can be properly analysed before granting the permission. In London, all planning documents are kept online for 10years and archived after that.

It is important to note that, once the historic buildings are being listed and reused, for any king of purposes, besides contributing to the preservation of cultural heritage, it also serves as a way of documentation the building.

\section{REFERENCES}

Bonduki, N., 2010. Intervenções urbanas na recuperação de centros históricos. Brasilia, DF: Iphan/Programa Monumenta.

Brand, S., 1994. How buildings learn: what happens after they are built. Viking Penguin, New York.

Castriota, L.B., 2007. Intervenções sobre o patrimônio urbano: modelos e perspectivas. In: FORUM Patrimônio: ambiente construtivo e patrimônio sustentável, Belo Horizonte, Brasil, Vol. 1, n.1, pp.9-31.

Choay, F., 2006. A alegoria do patrimônio. 3.ed. UNESP, São Paulo.

Stevenson, M., 2006. Regeneration through heritage: understanding the development potential of historic european arsenals. English Library, Swindon.

Hall, P., 1996. Cities of tomorrow: An intellectual history of urban planning and design in the twentieth century. Blackwell Publishers, Oxford.

Kühl, B., 2008. Preservação do Patrimônio Arquitetônico da Industrialização: Problemas teóricos de Restauro. Ateliê Editorial, Cotia.

Mason, R., 2002. Assessing values in conservation planning: methodological issues and choices. In: De la Torre M., Assessing the values of cultural heritage, Getty Conservation Institute, Los Angeles.

Mccaig, I., 2013. Practical Building Conservation Basis. Ashgate Publis- hing Limited, Farnham.

Viñas, S., 2005. Contemporary Theory of Conservation. Elsevier Butterworth-Heinemann, Oxford. 